EAJ (Economic and Accounting Journal)

Vol. 4, No. 1, Jan. 2021

ISSN 2615-7888

Received: Jul. 17,2020; Revised: Dec. 10, 2020; Accepted: Jan. 27, 2021; Published: Jan. 31, 2021

\title{
THE INFLUENCE OF KAP SIZE, INSTITUTIONAL OWNERSHIP, AND AUDIT COMMITTEE ON THE QUALITY OF FINANCIAL STATEMENTS
}

\author{
${ }^{1}$ Adris Kuncoro, ${ }^{\mathbf{2} D h i n i}$ Suryandari \\ ${ }^{1,2}$ Universitas Negeri Semarang \\ Email: adriskuncoro@gmail.com
}

\begin{abstract}
This research aims to examine the relationship between KAP size, institutional ownership, and the audit committee on the quality of financial reports. 616 Indonesian Stock Exchange (IDX) companies in 2018 became the population in this study. Purposive sampling as a sampling technique resulted in 547companies. Using inferential logistic regression analysis and using descriptive statistical analysis hypothesis testing methods with IBM SPSS version 25 tools. This study found that the KAP size and the audit committee has a positive effect on the quality of financial reports. Institutional ownership does not affect the quality of financial reports. Simultaneously, KAP size, institutional ownership, and audit committee influence the quality of financial reports. This study concludes that partially, KAP size and audit committee has a positive effect on the quality of financial reports. Simultaneously, KAP size, institutional ownership, and audit committee affect the quality of financial reports. Further research suggests using other proxies, other periods, and other variables.
\end{abstract}

Keywords: KAP Size; Institutional Ownership; Audit Committee; Quality of Financial Statements

\section{INTRODUCTION}

The use of financial reports and the presentation of financial statements is closely related to the quality of financial statements. When users of financial statements get information that can be trusted and is following the actual conditions of the company in the financial statements so that users can make good decisions. Deceived by financial reports that provide false information and are not following the circumstances of the company. Errors when receiving wrong information will only harm users of financial statements and benefit certain parties. The use of financial statement information is based on reporting by 
company management. The use of financial statement information is based on reporting by company management.

In Indonesia, the quality of financial reports is important to users, but there are still some cases that show fraud that occurs in financial reports. Some fraud may be discovered by the audit committee of public accountants. Audit committees and public accountants work to help maintain the quality of financial reports and assure users of financial reports. Information gaps can be reduced by the existence of financial reports but inconclusive reports can report information.

Information asymmetry in agency theory is the information gap between agents as managers and shareholders as principals. Agents have a better understanding of internal information and company developments than do shareholders or principals. Rachmawati (2008) financial reports are one way to reduce information asymmetry. Financial reports are a source of company financial information to interested parties and external parties who need information about the company. The relationship that appears in agency theory is an agency relationship, where the principal employs an agent and is in charge of making decisions.

The presentation of financial statements has been monitored internally by the audit committee and externally by a public accountant.
This supervision aims to minimize any fraud by management or any misstatements that arise. Financial reports can be said to be of quality by having four types of characteristics that are understandable, useful, reliable, and relevant. From several factors studied, the selection of the KAP size, institutional ownership, and the audit committee.

\section{LITERATURE REVIEW AND HYPOTHESIS DEVELOPMENT}

\section{Agency Theory}

The agent is a management and the principal is the owner or shareholder. There are rights and obligations between agents and principals. The owner is obliged to reward the agent for carrying out his duties as management (Hendriksen, Eldon. S., Breda, (1992). According to Meckling \& Jensen (1976), the relationships that exist in agency theory include relationships between individuals or groups such as contractual relationships. The principal as the employer gives the agency authority to make decisions. In agency theory, there are information gaps or information asymmetry. This gap arises between agents as managers and owners or shareholders as principals. The existence of this information gap is due to the manager as an agent have a better understanding of the condition 
EAJ (Economics and Accounting Journal) - Vol. 4, No. 1, Jan. 2021 - Kuncoro \& Suryandari

of the company and future targets than shareholders or principals.

\section{KAP Size}

Setiami \& Solikhah (2017) in their research, results showed that the opinion of financial statements, except for unqualified (WTP). So that it can be predicted that in the future the company can change to choose a better Public Accounting Firm (KAP). Sitorus (2019) results show that companies that use the Big Four KAP will guarantee the quality of their financial reports. The big four KAP auditors have been given training and procedures that are more accurate, using a more capable audit program than the non-big four accounting firms. The relationship with agency theory is that the KAP size affects the audit results of the financial statements. KAP can reduce the occurrence of recording errors or fraud committed by company management. Unqualified Opinions issued by the auditor without conducting rigorous substantive testing can be of lower quality (Tang et al., 2016). Based on this description, the researcher believes that KAP with a larger size can improve the quality of financial reports. This is because the size of KAP can illustrate the ability of auditors to minimize errors in financial statements.
H1: Partially, the KAP size has a positive effect on the quality of financial reports.

\section{Institutional Ownership}

Institutional ownership according to Rosyida, A. Q \& Siska (2018) can minimize the information asymmetry gap between management and shareholders by using the supervisory function effectively. The relationship with agency theory is that institutional ownership is likely to influence the information asymmetry that will arise. (Rahayuni et al., 2018) institutional ownership can act as a watchdog to increase intellectual capital disclosure. Based on this description, the researcher stated that with institutional ownership, the quality of the reports could be improved. This is because institutional ownership can minimize the possibility of problems in the institution. Based on this description, it can be assumed that the higher or greater the institutional ownership, the better the quality of the company's financial statements.

$\mathrm{H} 2$ : Partially, institutional ownership has a positive effect on the quality of financial reports.

\section{Audit Committee}

The establishment of the audit committee aims to help carry out the duties of the board of commissioners and supervise financial reports by applicable standards and free from 
misstatement (Indrasari et al., 2016). Siallagan \& Machfoedz (2006) the audit committee helps reduce the possibility of fraud and reduce misstatements that appear on financial statements. The presence of an audit committee in agency theory affects the asymmetry of information that management will convey in its financial statements, audit committees can minimize fraud by management. Nurochman \& Solikhah (2015) The audit committee can become supervisors and improve manager performance so that it has a positive effect on earnings persistence. Researchers believe the audit committee can improve the quality of financial reports. This is because the audit committee can minimize the possibility of problems in silence. the existence of an audit committee can improve the quality of financial statements.

H3: Partially the audit committee has a positive effect on the quality of financial reports.

\section{KAP Size, Institutional Ownership and Audit Committee}

H4: Simultaneously the KAP size, institutional ownership, and audit committee affect the quality of financial reports.

\section{RESEARCH METHOD}

Using quantitative analysis techniques with descriptive statistical analysis and inferential logistic regression analysis. Quantitative methods are statistically analyzed to test existing hypotheses (Sugiyono, 2017). This research design uses hypothesis testing research to determine the causal relationship between the variables of this study. The dependent variable in this study uses dummy calculations.

\section{Data Collection Techniques}

Research data is secondary data through data collection using documentation techniques. The data source is taken from the Indonesia Stock Exchange.

\section{Operational Definitions of Variables}

Financial Report Quality

Ikatan Akuntan Indonesia (2016) financial information is very useful if the existing information is comparable, verifiable, timely, and understandable. Using dummy measurements, companies with an unqualified opinion and timely financial report reporting are given code 1. Companies that do not own both are assigned code 0 .

\section{KAP Size}

Nariman (2015) KAP can be differentiated based on the size of KAP, namely large KAP (Big four) and small KAP (KAP Non-Big Four). Using dummy measurements, KAP Non-Big four gets code 0 and KAP big four gets code 1 . 
EAJ (Economics and Accounting Journal) - Vol. 4, No. 1, Jan. 2021 - Kuncoro \& Suryandari

\section{Institutional Ownership}

Susiana (2007) defines institutional ownership as ownership of shares owned by other companies in the country or abroad. Using the percentage of institutional ownership in the company.

\section{Audit Committee}

OJK Regulation Number 55/POJK.04/2015, the Audit Committee has a duty to assist the board of commissioners and the audit committee is formed by the board of commissioners. The number of members of the audit committee in the company.

\section{Sample Collection Techniques}

Secondary data comes from financial reports and audit reports of all companies on the IDX in 2018.
Selection of samples that match the criteria in the existing population, using purposive sampling technique to obtain a representative sample.

\section{Data Analysis Techniques}

Using inferential logistic regression analysis and using descriptive statistical analysis hypothesis testing methods with IBM SPSS version 25 tools.

\section{RESULTS AND DISCUSSION}

\section{Results}

\section{Descriptive Test}

The descriptive test produces the frequency, minimum, maximum, and average of the independent variables at 547 companies

Table 1: Descriptive test

\begin{tabular}{lcrrrr}
\hline & Frequency & Percent & $\begin{array}{c}\text { Valid } \\
\text { Percent }\end{array}$ & $\begin{array}{c}\text { Cumulative } \\
\text { Percent }\end{array}$ \\
\hline Financial & low quality & 44 & 8 & 8 & 8 \\
Report & high quality & 503 & 92,0 & 92,0 & 100,0 \\
Quality & Total & 547 & 100,0 & 100,0 & \\
KAP & NonBig4 & 362 & 66,2 & 66,2 & 66,2 \\
Size & Big4 & 185 & 33,8 & 33,8 & 100,0 \\
& Total & 547 & 100,0 & 100,0 & \\
\hline
\end{tabular}

Source: Results of data processing with IBM SPSS V.25, 2020

Table 2: Descriptive test

\begin{tabular}{lrrrrr}
\hline & $\mathrm{N}$ & Minimum & Maximum & Mean & Std. Deviation \\
\hline Institutional Ownership & 547 & 1,63 & 100,00 & 68,2793 & 20,81571 \\
Audit Committee & 547 & 1 & 6 & 3,0987 &, 48166 \\
\hline
\end{tabular}

Source: Results of data processing with IBM SPSS V.25, 2020 
EAJ (Economics and Accounting Journal) - Vol. 4, No. 1, Jan. 2021 - Kuncoro \& Suryandari

Table 3: Overall Model Fit

\begin{tabular}{cr}
\hline & $\mathbf{- 2}$ Log Likelihood \\
\hline -2 Log Likelihood Awal (Block Number = 0) & 334,954 \\
-2 Log Likelihood Akhir (Block Number = 1) & 329,535 \\
\hline Source: Results of data processing with IBM SPSS V.25, 2020
\end{tabular}

Table 4: Coefficient of Determination

\begin{tabular}{rrrr}
\hline \multicolumn{3}{c}{ Model Summary } \\
Step & -2 Log likelihood & Cox \& Snell R Square & Nagelkerke R Square \\
\hline 1 & $290,839^{\mathrm{a}}$ &, 028 &, 064 \\
\hline
\end{tabular}

Source: Results of data processing with IBM SPSS V.25, 2020

Table 5: Eligibility of Regression Models

\begin{tabular}{cccc}
\hline \multicolumn{5}{c}{ Hosmer and Lemeshow Test } \\
Step & Chi-square & $d f$ & Sig. \\
\hline 1 & 10,681 & 8 &, 220 \\
\hline Source: Results of data processing with & IBM SPSS V.25, 2020
\end{tabular}

Table 6: Partial test

\begin{tabular}{lccccrr}
\hline & \multicolumn{7}{c}{ Variables in the Equation } & & \\
& $\mathrm{B}$ & S.E. & Wald & df & Sig. & Exp(B) \\
\hline KAP Size &, 896 &, 430 & 4,340 & 1 &, 037 & 2,450 \\
Institutional &, 002 &, 007 &, 078 & 1 &, 780 & 1,002 \\
Ownership & & & & & & \\
Audit Committee & 1,155 &, 437 & 6,969 & 1 &, 008 & 3,173 \\
$\quad$ Constant & $-1,397$ & 1,381 & 1,022 & 1 &, 312 &, 247 \\
\hline
\end{tabular}

Source: Results of data processing with IBM SPSS V.25, 2020

Table 7: Simultaneous test

\begin{tabular}{|c|c|r|r|r|}
\hline \multicolumn{5}{|c|}{ Omnibus Tests of Model Coefficients } \\
\hline \multirow{2}{*}{} & Chi-square & df & \multicolumn{1}{c|}{ Sig. } \\
\hline \multirow{3}{*}{ Step 1 } & Step & 15,306 & 3 &, 002 \\
\cline { 2 - 5 } & Block & 15,306 & 3 &, 002 \\
\cline { 2 - 5 } & Model & 15,306 & 3 &, 002 \\
\hline
\end{tabular}

Source: Results of data processing with IBM SPSS V.25, 2020

\section{Overall Model Fit}

Overall model testing aims to determine whether the regression model is under existing information or not. This test uses -2 LogLikelihood Block Number $=0$ and 
EAJ (Economics and Accounting Journal) - Vol. 4, No. 1, Jan. 2021 - Kuncoro \& Suryandari

Block Number $=1$. The table information shows that Block Number $=0$ is 334,954 and Block Number $=1$ is 329,535 . The smaller value of Block Number 1 indicates the addition of independent variables of KAP size, institutional ownership, and audit committee into the logistic regression model, corrects the data model, and ensures that there are no differences between the model and observation information.

\section{Coefficient of Determination}

Nagelkerke R Square has a value of 0.064 which proves that there are $6.4 \%$ of the dependent variable which can be explained by the independent variable. While the remaining $93.6 \%$ is determined by independent variables outside this research model.

\section{Eligibility of Regression Models}

Based on the Hosmer and Lemeshow test above, it shows a significance value of $220>0.05$. The model can predict the value of observations. The null hypothesis can be accepted so that the model can be said to be appropriate and by existing observation information.

\section{Regression Model Analysis}

The logistic regression equation in this study can be described as follows: KLap $=-1,397+$ $0,896 \mathrm{UKAP}+0,002 \mathrm{KI}+1,155 \mathrm{KA}$

a) The KAP size variable (UKAP) has a coefficient of 0.896 with an odds ratio of 2.450 obtained. The coefficient is positive, which means that if other variables are considered constant, the chance for the quality of financial statements will increase by 2.450 for every 1 unit increase in UKAP.

b) Institutional Ownership (KI) has a coefficient of .002 with an odds ratio of 1.002 . The coefficient is positive, meaning that if other variables are considered constant, then the chances of the quality of the financial statements will increase by 1.002 factors for every increase of 1 unit of KI.

c) The Audit Committee (KA) has a coefficient of 1.155 with an odds ratio of 3.173. The coefficient is positive, which means that if other variables are considered constant, the chances of the quality of financial statements will increase by 3,173 factors for every increase of 1 unit of KA.

\section{Partial Test}

1. Testing the first hypothesis (H1) on the KAP size variable. Based on the measurement results obtained KAP beta coefficient of 0.899 with a 0.037 significance value which proves that hypothesis is accepted because of the Sig value of $0.037<0.05$.

2. Testing the second hypothesis (H2) of institutional ownership variables. Based on the research results, institutional ownership produces a beta coefficient of 
EAJ (Economics and Accounting Journal) - Vol. 4, No. 1, Jan. 2021 - Kuncoro \& Suryandari

0.002 with a Sig value of 0.780 . These results prove that the hypothesis is unacceptable because $\mathrm{Sig}$ value 0.780 is greater than the error rate $(\alpha)$ of 0.05 .

3. Testing the third hypothesis (H3) of the audit committee variable. Based on the research results, audit committee has a Sig value of 0.008 and a beta 1.155 . These results prove that the hypothesis can be accepted because 0.008 $<0.05$, the significance value is smaller than the error rate $(\alpha)$ of 0.05 .

\section{Simultaneous Test}

Test the fourth hypothesis

(H4) of the simultaneous effect between KAP size, institutional ownership, and audit committee. The level of significance in the table above is 0.002 and the Chi-square is 15.306. Test Chi-square significance value of 0.05 or table Chi-square value of the 3 variables at 7.815 . The Chi-square value is $15,306>7,815$, the Chi-square value is greater than the table value which explains that simultaneously the independent variable affects the dependent variable.

\section{Discussion}

The Effect of KAP Size on the Quality of Financial Statements

The first hypothesis is accepted, KAP size affects the quality of financial reports. Febrita \& Ari (2019) Non-Big Four Public
Accounting Firms in conducting audits of small companies have shortcomings in encouraging clients to clearly show their strengths and weaknesses. The size of the KAP can describe the capabilities of an auditor. This proves that the auditor of the Big Four KAP is considered to have better quality than the auditor of the NonFour Big KAP. It is concluded that the size of KAP can help reduce the emergence of information asymmetry between company management and stakeholders or company owners.

\section{The Effect of Institutional Ownership on the Quality of Financial Statements}

The second hypothesis is not accepted, institutional ownership affects the quality of financial reports. Institutional ownership is the ownership of company shares by other institutions. The oversight exercised by institutional ownership does not necessarily help reduce information asymmetry or improve firm performance. Because giving more ownership doesn't necessarily mean that you have the power or the will to better monitor company executives. In the research of Yasser et al (2017) it was found that institutional ownership is negatively related to earnings management in Pakistan. Meanwhile, in Malaysia, individual ownership and institutional ownership have a positive relationship. (Mahliza, 2019) The quality of internet financial reporting is not influenced by institutional 
ownership. The conclusion that can be drawn is that institutional ownership in Indonesia in 2018 has no significant effect on the quality of financial statements.

\section{The Effect of the Audit Committee on the Quality of Financial Statements}

The third hypothesis is accepted, The quality of financial reports can be improved by the audit committee as the internal supervisor. Internal control in the company can be carried out properly, guided by applicable standards, the findings can be followed up by management (Sofia, 2018). Gautama et al., (2017) also support the results of research with the results of the competence of the audit committee as one of the factors that improve the quality of financial statements. The number of audit committees in companies in Indonesia can affect the level of supervision carried out by the company, The optimal number of audit committee members can increase the supervision carried out. Supervision can provide positive results in the form of decreased information asymmetry that arises about agency theory. The existence of an audit committee can reduce the asymmetry of existing information. Increased supervision owned by the company has an impact on improving the quality of financial reports.

Effect of KAP Size, Institutional Ownership, and Audit Committee

\section{on the Quality of Financial} Statements

The fourth hypothesis is accepted, simultaneously the KAP size variable, institutional ownership, and the audit committee affect the quality of financial reports. In agency theory, it is explained that the KAP size, institutional ownership, and audit committee helps reduce the asymmetry of existing information. Agency theory explains that agency problems are caused by differences in conflicts of interest between those who run company operations and the company owners. KAP size, institutional ownership, and audit committee can reduce the asymmetry of existing information. Agency theory can represent independent variables and have a relationship with one another. Prove that the three independent variables have an effect on the quality of financial statements.

\section{CONCLUSION}

The KAP size and the audit committee affect the quality of the company's financial statements on the IDX in 2018. Partially there is no influence between institutional ownership on the quality of financial reports on the IDX in 2018. Simultaneously, KAP size, institutional ownership, and audit committee affect the quality of the company's financial statements on the IDX in 2018. Future research is expected to add to the research period 
EAJ (Economics and Accounting Journal) - Vol. 4, No. 1, Jan. 2021 - Kuncoro \& Suryandari

or have other variables and expand the determination of the quality of financial report results. Can use other proxies in measuring each research variable, to obtain the accuracy of the results and can explain the quality of financial reports more broadly and better. Companies are expected to be able to use the audit committee and KAP properly, to improve the quality of financial reports.

\section{REFERENCES}

Febrita, R. E., \& Ari, B. K. (2019). Kualitas Laporan Keuangan Perusahaan Publik di Indonesia. Jurnal Akuntansi: Kajian Ilmiah Akuntansi, 6(2), 157177.

Gautama, E., Daromes, F. E., \& Ng, S. (2017). Peran Moderasi Kompetensi Komite Audit pada Hubungan Antara Struktur Kepemilikan dan Kualitas Pelaporan Keuangan. Jurnal Akuntansi, 11(1), 68-98.

Hendriksen, Eldon. S., Breda, M. F. V. (1992). Accounting Theory. (Fifth Edit). Richard D. Irwin Inc.

Ikatan Akuntan Indonesia. (2015).

Pernyataan Standar Akuntansi Keuangan (PSAK). Salemba Empat: Jakarta.

Indrasari, A., Yuliandhari, W. S., \&

Triyanto, D. N. (2016). Pengaruh komisaris independen, komite audit, dan financial distress terhadap integritas laporan keuangan. Jurnal Akuntansi, 20(1), 117133.

Mahliza, F. (2019). Effect Of Gcg And Financial Performance On The Quality Of Internet Financial Reporting. EAJ (Economics And Accounting Journal), 2(1), 52-62.

Meckling, W. H., \& Jensen, M. C. (1976). Theory of the firm: Managerial behavior, agency costs and ownership structure. Journal of Financial Economics, 3(4), 305-360.

Nariman, A. (2015). Pengaruh Ukuran Kantor Akuntan Publik Terhadap Opini Going Concern Dan Earnings Response Coefficients (Erc) Pada Perusahaan Manufaktur Yang Terdaftar Di BEI Tahun 20112013. Jurnal Akuntansi, 19(2), 160-178.

Nurochman, A., \& Solikhah, B. (2015). Pengaruh Good Corporate Governance, Tingkat Hutang dan Ukuran Perusahaan terhadap Persistensi Laba. Accounting Analysis Journal, 4(4).

Otoritas Jasa Keuangan. (2015).

Peraturan Otoritas Jasa Keuangan Nomor 55/POJK. 04/2015 tentang pembentukan dan pedoman pelaksanaan kerja 
EAJ (Economics and Accounting Journal) - Vol. 4, No. 1, Jan. 2021 - Kuncoro \& Suryandari

komite audit. Jakarta: Otoritas Jasa Keuangan.

Rachmawati, S. (2008). Pengaruh faktor internal dan eksternal perusahaan terhadap audit delay dan timeliness. Jurnal Akuntansi Dan Keuangan, 10(1), 1-10.

Rahayuni, N., Solikhah, B., \& Wahyudin, A. (2018). Mampukah Kinerja Keuangan Memediasi Pengaruh Mekanisme Corporate Governance Terhadap Pengungkapan Modal Intelektual? Jurnal Kajian Akuntansi, 2(1), 67-81.

Rosyida, A. Q., \& Siska, P. Y. (2018). Pengaruh mekanisme corporate governance dan kualitas audit terhadap integritas laporan keuangan. E-Proceding of Management, Vol.5 No.2.

Setiami, N. D., \& Solikhah, B. (2017). Public Accounting Firm Switching on the Companies Listed in IDX. Jurnal Dinamika Akuntansi, 9(1), 23-32.

Siallagan, H., \& Machfoedz, M. (2006). Mekanisme corporate governance, kualitas laba dan nilai perusahaan. Simposium Nasional Akuntansi IX. Padang, 23-26.

Sitorus, A. (2019). Pengaruh Kualitas Auditor Terhadap Kualitas Laporan Keuangan pada Perusahaan Go Public yang Terdaftar di BEI.
Sofia, I. P. (2018). Pengaruh Komite Audit Terhadap Integritas Laporan Keuangan dengan Whistleblowing System Sebagai Variabel Moderasi. Jurnal Riset Akuntansi Terpadu, 11(2).

Sugiyono, P. D. (2017). Metode Penelitian Pendidikan: Pendekatan Kuantitatif, Kualitatif, R\&D. Bandung: $C V$ Alfabeta.

Susiana, A. H. (2007). Analisis pengaruh independensi, mekanisme corporate governance, dan kualitas audit terhadap integritas laporan keuangan. Simposium Nasional Akuntansi X.

Tang, Q., Chen, H., \& Lin, Z. (2016). How to measure country-level financial reporting quality? Journal of Financial Reporting and Accounting.

Yasser, Q. R., Al Mamun, A., \& Hook, M. (2017). The impact of ownership structure on financial reporting quality in the east. International Journal of Organizational Analysis. 